\title{
Kompetensi Lulusan Sarjana Ekonomi Syariah Dalam Dunia Kerja (Urgensi dan Harapan)
}

\author{
DAHARMI ASTUTI* \\ DESWITA MAHARANI**
}

\author{
*Fakultas Agama Islam (FAI) Universitas Islam Riau (UIR) \\ Jl. Kaharuddin Nasution No.113 Perhentian Marpoyan Pekanbaru 28284 \\ Telp : (0761) 45005 email: dheastuti72@yahoo.co.id \\ **Fakultas Agama Islam (FAI) Universitas Islam Riau (UIR) \\ Jl. Kaharuddin Nasution No.113 Perhentian Marpoyan Pekanbaru 28284 \\ Telp : (0761) 45005
}

\begin{abstract}
Abstrak: Tulisan ini diangkat dari penelitian dan skripsi mahasiswi Fakultas Agama Islam yang diampu oleh penulis dalam kerangka untuk membahas tentang sejauhmana kompetensi lulusan sarjana ekonomi Syariah dalam menghadapi dunia kerja. Tulisan ini membahas betapa pentingnya kita mengetahui sejauhmana tingkat kemampuan dan kompetensi yang dimiliki lulusan/alumni Fakultas Agama Islam dan mengetahui upaya apa saja yang dilakukan FAI UIR Prodi Ekonomi Syariah dalam mempersiapkan Lulusan Sarjana Ekonomi Syariah yang berkualitas. Penelitian ini diharapkan dapat menjadi acuan, masukan dan perbaikan mutu serta berdaya guna di masa yang akan datang.
\end{abstract}

Kata kunci: kompetensi lulusan, ekonomi syariah, dunia kerja

\section{PENDAHULUAN}

Prodi Ekonomi Syariah (yang mulanya bernama Ekonomi Islam) adalah salah satu program studi di Fakultas Agama Islam. Prodi ini berdiri pada tahun 2001. Setelah sekian lama berdiri, maka dirasakan perlu untuk melakukan penelitian, evaluasi dan monitoring sejauh mana dan bagaimana kompe-tensi alumni yang telah dikeluarkan oleh prodi tersebut, sebab tanpa dilakukan penelitian terhadap kompetensi alumni, kita tidak akan mendapatkan data perkembangan mutu dan kualitas program studi selama ini.
Di samping itu, prodi juga menyadari dalam perjalanannya masih banyak kekurangan disana sini, untuk itu perlu dilakukan penelitian yang mendalam, sekaligus sebagai upaya untuk evaluasi dan mengumpulkan data alumni yang selama ini masih belum tersusun dengan baik sehingga diharapkan ada hubungan yang integral antara program studi dan alumni.

Sebagaimana yang kita ketahui, bahwa perkembangan ekonomi syariah dan industri perbankan syariah serta lembaga-lembaga keuangan syariah lainnya adalah sangat signifikan. Perkembangan ini tentunya harus 
diimbangi dengan tersedianya Sumber Daya Manusia (SDM) yang memadai, baik dari segi kuantitas maupun kualitas. Tanpa SDM yang memadai, mustahil lembaga-lembaga tersebut dapat menjalankan peran dan fungsinya dengan baik (Naqvi, 2003:139).

Di tengah arus perkembangan seperti ini, maka diperlukan lembaga untuk menjadi pusat kajian dan pengembangan ekonomi syariah. Dalam hal ini, yang semestinya menjadi pusat kajian dan pengembangan ekonomi syariah adalah perguruan tinggi yang memiliki visi dan misi kajian serta pengembangan ekonomi syariah tersebut (Fauroni, 2006:58).

Perguruan tinggi sebagaimana yang dipahami bukanlah Menara gading. Perguruan tinggi harus mempunyai standarisasi yang jelas baik pada visi dan misinya, kualifikasi kemampuan dosen-dosennya, kurikulum dan profil kualifikasi out put yang dihasilkannya. Pembidangan keilmuan Perguruan Tinggi Agama Islam pada dasarnya harus mengedepankan aspek metodologi keilmuannya dan disepakati oleh para cendekiawan (intelectual community) (Fauroni, 2006: 59).

Dalam rangka penyediaan SDM yang dibutuhkan oleh industri perbankan syariah dan lembagalembaga keuangan syariah lainnya, maka Program Studi (Prodi) Ekonomi Syariah hadir dengan satu tekad yaitu agar menjadi institusi perguruan tinggi yang unggul, berkualitas dan memberikan kontribusi terbaiknya dalam menyokong tumbuh kembangnya ekonomi syariah di Indonesia dan dalam rangka menebarkan sebanyakbanyaknya kemaslahatan untuk bangsa dan negara serta bagi umat Islam khususnya dan rakyat Indonesia umumnya.

Hadirnya Prodi Ekonomi Syariah dalam kelembagaan akademiknya, bukan dimaksudkan untuk memisahkan secara diametral antara ilmu ekonomi syariah dengan ekonomi konvensional. Ekonomi syariah, lebih bermakna penggalian dan pengembangan keilmuan dalam bidang ekonomi yang berlandaskan pada wahyu Al-Qur'an dan Hadis.

Dalam bahasa lain, ekonomi syariah merupakan penggalian khazanah yang telah ada dalam rangkaian sejarah peradaban Islam yang panjang untuk diaktualisasikan pada masa sekarang. Bukti-bukti tentang bagaimana perilaku ekonomi yang diajarkan oleh Nabi Muhammad merupakan fakta historis yang tidak dapat disangkal. Demikian pula, buktibukti ajaran Islam baik yang bersumber langsung dari Al-Qur'an dan hadits maupun dari penafsiran dan pemikiran para pemikir muslim. Karena itu, salah satu tujuan ekonomi syariah adalah optimalisasi kontribusi yang dimilikinya terhadap sistem dan perekonomian kontemporer. Oleh sebab itu, hadirnya ekonomi syariah diharapkan dapat menjadi alternatif baik sebagai bangunan teoritis maupun praktisnya dalam melakukan pembangunan manusia dan peradabannya.

Sejak dikeluarkannya SK Direktorat Jendral Kelembagaan Agama Islam Departemen Agama RI No. E/10 pada tanggal 16 Januari 2002, yaitu gelar pendidikan akademik strata satu di Indonesia mengenal Sarjana Ekonomi Islam (S.E.I) dan kemudian diganti menjadi Sarjana Ekonomi Syariah (S.E.Sy) berarti pemerintah merespon positif terhadap perkembangan ekonomi syariah dengan hadirnya lembaga keuangan syariah serta perguruan tinggi yang menyelenggarakan pendidikan di bidang tersebut (Fauroni, 2006:46).

Idealitas di atas sebetulnya telah tersurat jelas dalam Pasal 3 SK 
Mendiknas No. 232/U/2002 tentang arah Perguruan Tinggi Program Sarjana menerapkan dasar-dasar ilmiah dan keterampilan pada bidang keahliannya, mampu memahami dan menyelesaikan masalah dalam kawasan keahliannya untuk kegiatan produktif dan bermanfaat bagi kehidupan bersama yang dikemukakan Admin (http://isjd.pdii.lipi.go.id/admin/jurnal, 2012:1).

Sarjana Ekonomi Syariah yang telah dibekali ilmu-ilmu teoritis sekaligus praktis diharapkan agar sebagian memilih menjadi pelamar pekerjaan, dan sebagiannya lagi memilih menjadi wirausaha, walaupun harus berangkat dari usaha kecilkecilan. Sistem bagi hasil mudharabah dan musyarakah memberikan peluang besar terhadap pilihan menjadi wirausahawan muda yang tangguh. Tentunya, wirausahawan profesional profetik, yang dapat menggabungkan antara nilai profesional kerja dan professional sebagai wirausahawan pada satu sisi dan nilai moralitas kenabian pada sisi lain (Nawawi, 2009:167).

Pada Januari 2012, tercatat 1,4 juta penduduk angkatan produktif di Indonesia sedang kesulitan dalam mencari lapangan pekerjaan. Bahkan sebagian besar dari jumlah tersebut merupakan pengangguran terbuka yaitu mereka yang sama sekali tidak memiliki penghasilan sedikitpun. Dengan tantangan riil itulah, maka hanya para sarjana yang memiliki kompetensi dan daya kompetitif tinggilah yang akan dapat meraih kesempatan lowongan pekerjaan yang terbatas tersebut (Fauroni, 2006:51).

Di sinilah, peran strategis yang harus dimainkan oleh Perguruan Tinggi Fakultas Agama Islam (FAI) Universitas Islam Riau (UIR), khususnya Prodi Ekonomi Syariah dengan mengambil peran penting dalam mempersiapkan SDM yang dibutuhkan semua lembaga yang disebutkan di atas. Berdasarkan hasil pra survai di FAI UIR, jumlah lulusan per tahunnya dapat dilihat pada tabel sebagai berikut:

\section{Tabel 1}

Perkembangan Jumlah Lulusan Ekonomi Syariah Fakultas Agama Islam Universitas Islam Riau pada Tahun 2004 s/d 2012

\begin{tabular}{cc}
\hline Wisuda & Jumlah Lulusan \\
\hline Tahun 2004 & 4 \\
\hline Tahun 2005 & 6 \\
\hline Tahun 2006 & 3 \\
\hline Tahun 2008 & 1 \\
\hline Tahun 2009 & 15 \\
\hline Tahun 2010 & 10 \\
\hline Tahun 2011 & 14 \\
\hline Tahun 2012 & 8 \\
\hline Total & $\mathbf{6 1}$ \\
\hline
\end{tabular}

Sumber Data: Tata Usaha FAI UIR Pekanbaru, 2012.

Dari tabel di atas dapat diketahui bahwa adanya kecendrungan naik turunnya jumlah lulusan per tahunnya. Dapat dilihat pada tahun 2004, jumlah lulusan sebanyak 4 orang. Dan pada tahun 2006, jumlah lulusan mengalami peningkatan dengan jumlah lulusan sebanyak 6 orang. Namun pada tahun 
2007 dan 2008, jumlah lulusan mengalami penurunan sebanyak 3 dan 1 orang. Pada tahun 2009 s/d 2011, jumlah lulusan mengalami peningkatan dan penurunan lagi dengan jumlah lulusan sebanyak 15, 10 dan 14 orang. Dan pada tahun 2012, jumlah lulusan mengalami penurunan dengan jumlah lulusan sebanyak 8 orang.

Berdasarkan informasi yang diperoleh dari Ketua Jurusan Ekonomi Syariah FAI UIR (Lolyta Permata, 2012), pada kenyataannya sebagian dari jumlah Lulusan Sarjana Ekonomi Syariah FAI UIR di atas, ada yang bekerja sesuai dengan disiplin ilmu (keahlian) yang ditekuninya selama di perguruan tinggi dan sebaliknya ada sebagian dari Lulusan Sarjana Ekonomi Syariah tersebut, bekerja tidak sesuai dengan disiplin ilmu yang ditekuninya selama di perguruan tinggi, dengan kata lain bekerja tidak sesuai dengan jurusan. Apabila ingin dikaji lebih dalam maka persoalan tersebut tidak akan ada habisnya untuk di bahas dan Lulusan Sarjana Ekonomi Syariah itupun tidak akan medapatkan pekerjaan apabila hanya mengandalkan jurusan. Oleh sebab itu, walaupun mereka bekerja tidak sesuai jurusan tetapi diharapkan dengan bekal kompetensi yang dimilikinya sebagai modal kedua setelah modal pertama keilmuannya, mereka dapat berkompetisi dan menembus industri dunia kerja. Dari permasalahan di atas, timbul pertanyaan apakah ada hubungan atau keterkaitan antara kompetensi yang dimiliki Lulusan Sarjana Ekonomi Syariah tersebut dengan dunia kerja yang digelutinya?

Setiap manusia yang telah mendapatkan titel sarjana mempunyai tanggung jawab sosial yang sangat berat karena mereka sebelumnya telah dipersiapkan untuk menjadi orang yang berguna dalam masyarakat. Setiap sarjana dalam melaksanakan tanggung jawab sosial, seperti pengabdian, harus mempunyai kemauan, sesuai dengan gelar yang diperolehnya dari perguruan tinggi (A. Rani Usman, 2001:56).

Dalam Kamus besar Bahasa Indonesia (2008:764), pengertian sarjana adalah orang pandai (ahli ilmu pengetahuan), gelar yang dicapai oleh seseorang yang telah menamatkan pendidikan terakhir di perguruan tinggi. Dengan kata lain, sarjana bukan hanya dapat diartikan sebagai seseorang yang telah menamatkan pendidikan terakhirnya di perguruan tinggi tetapi sarjana juga dapat diartikan kepada mahasiswa yang sedang belajar.

Dalam penelitian ini, penulis memfokuskan sarjana hanya kepada Lulusan Sarjana Ekonomi Syariah FAI UIR tahun 2004 s/d 2012 yang berkecimpung di dunia kerja. Dunia kerja adalah tempat atau tujuan terakhir para sarjana mengabdikan diri setelah lulus dari perguruan tinggi dalam melaksanakan tanggung jawab sosial kepada masyarakat (Antonio, 2001:255).

\section{Kerangka Teori}

Saat memasuki dunia kerja, kita sebagai seorang calon karyawan seringkali diharapkan memiliki kompetensi tertentu atas jabatan kerja yang kita masuki. Hal ini menjadi acuan bagi perusahaan untuk mengetahui kemampuan kerja kita sebagai calon karyawan. Tidak hanya itu, melalui kompetensi yang kita miliki, perusahaan lebih mengetahui posisi apa yang cocok dan tepat untuk kita. Bukan menjadi acuan baku bahwa kompetensi menjadi suatu hal paling penting untuk dimiliki seorang karyawan, tetapi sebagai calon karyawan kita perlu tahu kira-kira kompetensi seperti apa yang umumnya diinginkan perusahaan. Oleh sebab itu, dibutuhkan kemampuan atau 
kompetensi yang dimiliki dengan dunia kerja, agar keahlian (disiplin ilmu) yang diperoleh selama bangku perkuliahan sesuai dengan pekerjaan yang akan digeluti (Widilaksmi, 2012:1).

Berbicara tentang perguruan tinggi tidak terlepas dari manusia, yaitu dosen dan mahasiswa. Dosen adalah pengajar pada perguruan tinggi (Team Pustaka Phoenix, 2008:201). Sedangkan mahasiswa adalah orang yang belajar di perguruan tinggi (Team Pustaka Phoenix, 2008:556). Majunya sebuah Negara sangat bergantung pada sejauh mana perguruan tinggi tersebut mencetak sarjana atau kader-kader pemimpin bangsa. Kampus adalah tempat kegiatan perguruan tinggi berlangsung (Team Pustaka Phoenix, 2008:413). Kampus merupakan suatu unsur yang sangat penting dalam membangun mental dan spiritual suatu bangsa.

Peran perguruan tinggi dalam membina insan intelektual sudah menjadi kenyataaan. Artinya, setelah mahasiswa mengikuti bangku kuliah mereka telah mencoba mempersiapkan dirinya guna membangun bangsanya, baik melalui ide, konsep, maupun tindakan (Usman, 2001:ix).

Setiap tahun perguruan tinggi menciptakan dan melahirkan banyak sarjana dalam berbagai disiplin ilmu sehingga beragam pula lapangan pekerjaan serta bermacam peluang yang dapat diisi oleh para sarjana tersebut. Sarjana adalah orang pandai (ahli ilmu pengetahuan), gelar yang dicapai oleh seseorang yang telah menamatkan pendidikan tingkat terakhir di perguruan tinggi (Team Pustaka Phoenix, 2008:764). Untuk memperoleh titel tersebut, mahasiswa menempuh berbagai cara mulai dari persyaratan akademis sampai dengan keperluan lain yang berkaitan dengan perkuliahan (Usman, 2001:53).
Dalam penyelesaian tugas akhir memang rumit dan susah, namun semua itu harus dilaksanakan oleh mahasiswa yang bersangkutan pada detik-detik terakhir di perguruan tinggi, mahasiswa digolongkan sangat sibuk dibandingkan pada semester sebelumnya. Pada semester terakhir mahasiswa sudah mempersiapkan bahan dan perlengkapan lainnya yang berkenaan dengan penyelesaian skripsi atau laporan penelitian mahasiswa yang bersangkutan.

Setelah menyelesaikan urusan laporan, lantas menunggu keluarnya ijazah guna mencari kerja dimana ada lowongan. Kebanyakan sarjana tidak terkecuali disiplin ilmu apapun, setelah menjadi sarjana, dalam pikirannya cuma ada satu, yaitu kerja. Inilah realitas yang ada kini, dan hal ini adalah suatu kewajaran sebab kita sebagai manusia (Usman, 2001:59).

Dalam menghadapi tantangan hidup setelah menyelesaikan kuliah memang sangat sulit dibandingkan selama masih menjadi mahasiswa. Ada sarjana yang minder tentang kesarjanaannya sekaligus rasa rendah diri akan kemampuannya bahkan malu apabila disebut sarjana karena belum mendapat kerja.

Untuk mencari lapangan kerja memang adakalanya mudah. Akan tetapi, kadangkala tidak sesuai dengan keahlian (disiplin ilmu) yang ditekuninya selama di perguruan tinggi. Dalam Kamus Besar Bahasa Indonesia (2008:18), keahlian adalah kemahiran dalam suatu ilmu (kepandaian pekerjaan). Dalam hal ini, agar keahlian (disiplin ilmu) yang diperoleh selama bangku perkuliahan sesuai dengan pekerjaan yang digeluti dibutuhkan pengetahuan sejauhmana kompetensi yang dimiliki dalam dunia kerja.

Kompetensi adalah suatu keadaan dimana manusia itu sendiri memiliki 
kecakapan dan pengetahuan yang memadai dalam suatu hal atau pekerjaan (Team Pustaka Phoenix, 2008:471). Contohnya, Sarjana Ekonomi Syariah menjadi pegawai di bank syariah, bukan sebaliknya Sarjana Ekonomi menjadi satpam di bank. Jangankan ilmunya yang berkembang, ilmu yang sudah ada hilang dengan sendirinya. Demikian halnya dengan disiplin ilmu yang lain.

Mencari kerja di abad modern memang dibutuhkan orang-orang yang jeli dalam mencari informasi yang berkaitan dengan lowongan kerja. Kerja pada zaman sekarang dituntut hanyalah keterampilan dan kecakapan belaka. Tanpa keahlian dan kompetensi jangan harapkan kerjaan itu akan datang. Bagi yang keahlian maupun kompetensinya mempunyai hubungan atau keterkaitan dengan disiplin ilmu yang ia tekuni selama di perguruan tinggi, dirasa akan mudah mendapatkan lapangan pekerjaan karena keahlian dan kompetensinya mempunyai hubungan atau keterkaitan dengan dunia kerja yang ia geluti, apalagi yang ekonominya tinggi dan berasal dari keluarga terhormat tentunya kerja itu tidak begitu dipikirkan. Lain halnya dengan sarjana yang intelektualnya tidak menguntungkan ditambah lagi dengan ekonomi keluarganya tidak mengizinkan sekaligus hidupnya dalam kalangan kelas bawah. Mereka dalam mencari kerja tidaklah mudah, bahkan bagi mereka merupakan beban dan tantangan hidup yang lebih menyulitkan (Usman, 2001:60).

\section{DEFINISI DAN HAKIKAT EKONOMI SYARIAH}

Dewasa ini, beberapa ekonom muslim berusaha mendefinisikan ekonomi syariah, hal itu tidak lepas dari konteks permasalahan-permasalahan ekonomi yang mereka hadapi sehingga kesan yang terjadi dalam mendefinisikannya dipengaruhi oleh beberapa kondisi para ekonom muslim itu sendiri. Ini tidak lepas dari kenyataan bahwa kegiatan manusia dalam bidang ekonomi antara suatu masa dengan masa lain, daerah satu dengan yang lain berbeda disebabkan adanya perbedaan geografi, ideologi, dan demografi. Perbedaan pendefinisian ekonomi syariah di kalangan ilmuan dapat diartikan sebagai usaha para ekonom muslim untuk menyatakan masalah ekonomi (Idri dan Tutik, 2008). Akhirnya para ilmuan tersebut sepakat untuk mendefinisi ekonomi syariah, sebagai berikut: "Ekonomi syariah adalah pengetahuan dan penerapan hukum syariah untuk mencegah terjadinya ketidakadilan atas pemanfaatan dan pembuangan sumbersumber material dengan tujuan untuk memberikan kepuasan manusia serta mengamalkannya sebagai kewajiban kepada Allah dan masyarakat" (Muhamad, 2008:4).

Sedangkan ilmu ekonomi syariah adalah: "Studi tentang bagaimana individu atau masyarakat memilih dan menggunakan sumber daya yang ada, sekarang atau yang telah ditinggalkan oleh generasi masa lalu, sesuai aturan atau syarak (Al-Qur'an, hadis, atau hukum di bawahnya) yang digunakan untuk memenuhi kebutuhan jasmani dan rohani tanpa adanya eksploitasi sehingga dapat mewujudkan falah (kesejahteraan) bagi individu maupun masyarakat" (Muhamad, 2008:6).

Asumsi dasar atau norma pokok aturan main dalam proses maupun interaksi kegiatan ekonomi adalah syari'at Islam yang diberlakukan secara menyeluruh (kaffah atau totalitas) baik terhadap individu, keluarga, masyarakat, pengusaha, atau pemerintah dalam memenuhi 
kebutuhan hidup baik untuk keperluan jasmani maupun rohani. Dari beberapa definisi di atas, dapat disimpulkan bahwa prinsip ekonomi syariah ialah penerapan asas efisiensi dan manfaat dengan tetap menjaga kelestarian lingkungan alam. Motif Ekonomi syariah adalah mencari keberuntungan di dunia dan akhirat oleh manusia selaku khalifah Allah dengan jalan beribadah.

Berbeda dengan ekonomi konvensional, ekonomi syariah mendasarkan setiap aktivitas ekonomi pada ketentuan dan sumber ajaran Islam. Nilai-nilai yang terkandung dalam sumber ajaran itu yang menjadi pertimbangan dalam setiap aktivitas ekonomi. Sumber-sumber tersebut adalah Al-Qur'an, Hadist, Ijma', Qiyas, 'Urf, Istihsan, dan Maslahah Mursalah.

Sebagai kalam Allah yang merupakan mu'jizat yang diturunkan (diwahyukan) kepada Nabi Muhammad yang ditulis dalam mushaf dan diriwayatkan dengan mutawatir serta membacanya ibadah, Al-Qur'an merupakan sumber pokok dalam sistem ekonomi syariah. Keberadaan Al-Qur'an yang demikian sangat layak dan bahkan harus menjadi sumber utama ekonomi syariah. Ini berarti setiap konsep, ajaran, nilai, atau prinsip-prinsip dalam ekonomi syariah tidak diperkenankan dengan ketentuan Al-Qur'an. Ketentuan merupakan pedoman bagi manusia di setiap waktu dan dalam segala bidang termasuk bidang perekonomian yang meliputi pengelolaan pengeluaran harta, perdagangan, riba, utang piutang, dan sebagainya.

Hadits merupakan sumber hukum kedua setelah Al-Qur'an yang memerintahkan kaum muslimin agar mengikuti perilaku Nabi Muhammad, yang menjadi teladan dan sebagai penjelas ayat-ayat Al-Qur'an baik melalui sabda-sabda, perbuatan, sikap, dan perilakunya. Banyak ayat Al-Qur'an yang menyuruh umat muslim mengikuti Rasulullah yang juga sebagai manifestasi ketaatan kepada Allah. Ada beberapa model perilaku ekonomi yang dicontoh Nabi misalnya cara menjual barang yang benar, melakukan gadai, berserikat dalam bisnis dan sebagainya.

Selanjutnya Ijma', Ijma' merupakan kesepakatan semua mujtahid umat Nabi Muhammad. Dalam masa setelah beliau wafat tentang hukum syara' keberadaan Ijma' menjadi solusi pemecahan persoalan yang dihadapi umat muslim termasuk dalam bidang ekonomi karena dengan kesepakatan itu, perpecahan pendapat dapat dihindari dan umat muslim tinggal melaksanakan hasil kesepakatan tersebut. Karena itu, Ijma' merupakan faktor yang paling ampuh dalam memecahkan kepercayaan dan praktik rumit kaum muslimin pada suatu masa tertentu dan memiliki kesahihan dan daya fungsional yang tinggi.

Di kalangan umat muslim, jika persoalan tidak secara tegas diselesaikan dalam Al-Qur'an, hadits, atau ijma' maka mereka menyelesaikannya dengan qiyas atau metode ijtihad lain. Qiyas dapat didefinisikan dengan pemindahan hukum yang terdapat pada Ashl kepada Furu' atas dasar 'Illat yang tidak dapat diketahui dengan logika bahasa.

Di samping keempat sumber tersebut, Urf merupakan salah satu sumber inspirasi nilai-nilai ekonomi syariah. Urf' dapat diartikan dengan sesuatu yang diketahui dan dilakukan orang (Idri dan Tutik, 2008:15) atau sesuatu yang biasa dilakukan masyarakat muslim yang telah terinternalisasi dalam bentuk adat istiadat baik berupa perkataan, sikap, perbuatan, atau lainnya. Demikian halnya Istihsan, dapat menjadi pertimbangan untuk menyelusuri nilainilai ekonomi syariah dengan cara 
mendahulukan Qiyas Khafi (yang tersembunyi) dari Qiyas Qail (jelas) atau dari hukum Kulli (umum/global) kepada hukum Istisna'i (pengecualian) (Idri dan Tutik, 2008:15).

Di samping itu, nilai-nilai dan hukum ekonomi syariah dapat ditelusuri melalui metode Mashlahah AlMursalah yang berupa kemaslahatan yang disyariatkan oleh Allah dalam wujud hukum nash dalam rangka menciptakan kemaslahatan manusia. Nilai bidang ekonomi banyak yang sebagian tidak tersentuh nash dapat ditetapkan melalui mashlahah ini (Idri dan Tutik, 2008:15).

Dengan demikian, dapat dikatakan bahwa pada hakikatnya ekonomi syariah adalah subsistem keilmuan yang bersumber dari sumber-sumber ajaran Islam dalam hal yang menyangkut harta dan sumber daya ekonomi yang diberikan Tuhan kepada makhluk-Nya untuk meningkatkan kemakmuran umat manusia. Oleh karena itu, sesuai dengan ajaran Islam, ekonomi syariah mementingkan nilai kemakmuran, ketakwaan, peningkatan taraf kehidupan yang selaras antara material dan spiritual, pelaksanaan tanggung jawab sosial dan pelestarian lingkungan.

\section{Definisi Kompetensi}

Secara umum kompetensi dapat didefinisikan sebagai sekumpulan pengetahuan, keterampilan, sikap, dan nilai sebagai kinerja yang berpengaruh terhadap peran, perbuatan, prestasi, serta pekerjaan seseorang. Dengan demikian, kompetensi dapat diukur dengan standar umum serta dapat ditingkatkan melalui pendidikan dan pelatihan (Yulaelawati, 2004:16). Kompetensi merupakan perpaduan dari pengetahuan, keterampilan, nilai dan sikap yang direfleksikan dalam kebiasaan berfikir dan bertindak (Mulyasa, 2010:37-38).

Kompetensi merupakan karakteristik mendasar seseorang yang berhubungan timbal balik dengan suatu kriteria efektif atau kecakapan terbaik seseorang dalam pekerjaaan atau keadaan (Yulaelawati, 2004:16-17).

Ada lima tipe kompetensi, sebagai berikut menurut Spencer dan Spencer (1993:9-11): (1) Motif yaitu sesuatu yang dimiliki seseorang untuk berpikir secara konsisten atau keinginan untuk melakukan suatu aksi; (2) Pembawaan yaitu karakteristik fisik yang merespon secara konsisten berbagai situasi atau informasi; (3) Konsep diri yaitu tingkah laku, nilai atau citraan (image) seseorang; (4) Pengetahuan yaitu informasi khusus yang dimiliki seseorang; dan (5) Keahlian yaitu kemampuan untuk melakukan tugas secara fisik atau mental (Yulaelawati, 2004:17-18).

Kompetensi dikelompokkan ke dalam tiga kategori, sebagai berikut menurut Spencer, McClelland, dan Spencer (Yulaelawati, 2004:20): (1) Pengetahuan merupakan pengetahuan tentang fakta atau prosedur, seperti keanekaragaman makhluk hidup, anatomi tubuh manusia, berhitung, analisis keuangan, pelayanan dan jasa, serta komputer literasi; (2) Keterampilan merupakan keterampilan kognitif atau perilaku, seperti bekerja sama, membangun jaringan, membentuk kekeluargaan, membangun pengertian, dan membuat orientasi terinci; dan (3) Karakteristik personal merupakan ciri pembawaan individu, misalnya kemampuan menyesuaikan diri, percaya diri, kontrol diri, menegang stres, menyelesaikan konflik, prakarsa, kemandirian, integritas, dan kesadaran interpersonal.

Allah SWT berfirman: 


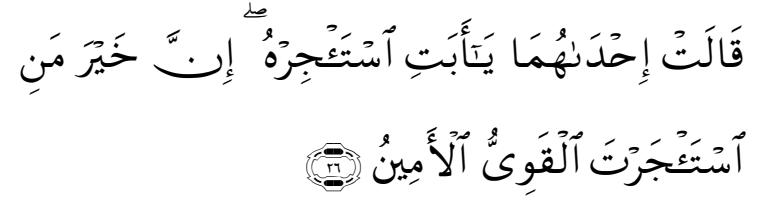

Artinya: "Salah seorang dari kedua wanita itu berkata: "Ya bapakku ambillah ia sebagai orang yang bekerja (pada kita), karena Sesungguhnya orang yang paling baik yang kamu ambil untuk bekerja (pada kita) ialah orang yang kuat lagi dapat dipercaya". ( Al-Qashash, 28: 26)

Sedangkan definisi kompetensi dalam hadis adalah "Sesungguhnya Allah suka kepada hamba yang berkarya dan terampil (professional atau ahli)". Barangsiapa bersusah-payah mencari nafkah untuk keluarganya maka dia serupa dengan seorang mujahid di jalan Allah Azza wajalla (HR. Ahmad). Dan apabila pekerjaan itu diserahkan kepada orang yang tidak ahlinya maka tunggulah kebinasaannya. Berdasarkan definisi kompetensi Al-Qur'an dan Hadis di atas, jelas bahwa kompetensi merupakan suatu kewenangan/ kemampuan yang dimiliki seseorang yang diaktualisasikan dalam pekerjaannya.

\section{Kompetensi Dasar Ekonomi Syariah}

Sebagai konsekuensi tidak terpisahkannya aktivitas ekonomi dengan nilai etika dalam dunia ekonomi, terdapat beberapa kompetensi yang perlu diperhatikan, sebagai berikut: (1) Kompetensi untuk kesadaran etika (ethical sensibility); (2) Kompetensi untuk berpikir secara etika (ethical reasoning); (3) Kompetensi untuk bertindak secara etika (ethical conduct); dan (4) Kompetensi untuk kepemimpinan etika (ethical leadership) (Idri dan Tutik, 2008:61).

Keempat kompetensi di atas merupakan tulang pungggung (backbound) watak manusia dan dapat menjadi lebih kuat jika diaplikasikan dalam kehidupan. Kompetensi kesadaran etis terlihat pada kapabilitas untuk menentukan aspek-aspek dari suatu situasi yang menuntut untuk menyadari bahwa suatu aktivitas ekonomi sesuai dengan etika atau tidak. Kesadaran ini akan muncul apabila seseorang terlebih dahulu mengetahui nilai-nilai etika. Dalam hal ini termasuk pula kemampuan untuk menerapkan etika yang umum pada situasi yang dihadapi dengan upaya peningkatan kesadaran akan pentingnya etika dalam ekonomi. Pendidikan etika dapat mengintrodusir prinsip-prinsip atau konsep etika yang khusus pada dunia ekonomi.

Kesadaran etika terlihat antara lain pada upaya menghindari ketidakadilan dan eksploitasi, dengan maksud melindungi hak-hak individu dalam masyarakat dan meningkatkan kesejahteraan umum agar terhindar dari kesenjangan. Kesenjangan harus diatasi dengan menggunakan cara, antara lain: (1) Menghapuskan monopoli, kecuali oleh pemerintah dalam bidang tertentu; (2) Menjamin hak dan kesempatan semua pihak untuk aktif dalam proses ekonomi, baik produksi, distribusi, sirkulasi, maupun konsumsi; (3) Menjamin pemenuhan kebutuhan dasar setiap anggota masyarakat; dan (4) Melaksanakan amanah dimana yang mampu menanggung dan membantu yang tidak mampu (Antonio, 2001:51).

Kesadaran etika dalam ekonomi tidak akan berjalan dengan sebagaimana diharapkan jika tidak dibarengi oleh kemampuan berpikir yang benar. Kompetensi berpikir etika dalam aktivitas ekonomi diperoleh melalui tiga pendekatan, sebagai berikut: (1) Menggunakan pandangan yang objektif (impartial perspective), 
yaitu dengan cara memikirkan sesuatu sesuai dengan adanya (das sein) dan bukan berdasarkan pandangan pribadi (subjektif ); (2) Meningkatkan prinsipprinsip pada tindakan umum dan universal, yaitu terdapat dasar pemikiran yang bersifat umum dan universal untuk dijadikan pijakan dalam bertindak; dan (3) Memperhatikan dan merpertimbangkan hak-hak dan kesejahteraan beberapa pihak yang dipengaruhi oleh keputusan, yaitu setiap keputusan harus dipikirkan secara matang agar memberikan keadilan pada setiap orang yang terkena ketentuan dalam keputusan itu.

Kompetensi bertindak secara etika mempunyai arti bahwa ketulusan hati akhirnya akan ditujukan dalam tingkah laku sesuai proses pengambilan keputusan secara etika yang benar. Situasi dalam bisnis yang penuh dengan godaan dan tekanan merupakan faktor signifikan yang perlu diperhatikan dalam hal ini. Kegagalan bertindak secara etika terjadi manakala orang yang bersalah tidak berani, atau tidak mau, mengakui kesalahannya secara jujur. Demikian pula, secara sadar orang melakukan pelanggaran hukum dalam berbisnis, tanpa penyesalan dan menganggap tindakannya benar.

Kejujuran, kebenaran, amanah, di samping adil sangat diperlukan dalam aktivitas ekonomi. Dalam Islam, kebenaran atau benar merupakan ruh keimanan, ciri pertama orang mukmin, bahkan ciri para nabi. Tanpa kebenaran, kehidupan tidak akan tegak dan tidak akan stabil. Sebaliknya, kebohongan atau dusta merupakan bagian dari sikap orang munafik. Menurut Yusuf AlQardlawi, bencana terbesar dalam aktivitas ekonomi saat ini adalah meluasnya tindakan dusta dan batil, misalnya berbohong dalam mempromosikan barang atau menetapkan harga. Oleh karena itu, salah satu karakter pedagang yang terpenting dan diridhoi Allah ialah kebenaran.

Perilaku benar yang mengandung kinerja yang baik sangat dihargai dan dianggap sebagai suatu investasi bisnis yang benar-benar menguntungkan, karena hal itu akan menjamin adanya kedamaian di dunia dan juga kebahagiaan di akhirat. Panduan tentang bagaimana perilaku seseorang itu benar diukur dan dinilai berdasarkan Al-Qur'an dan diselaraskan dengan perilaku Rasulullah. Allah SWT berfirman:

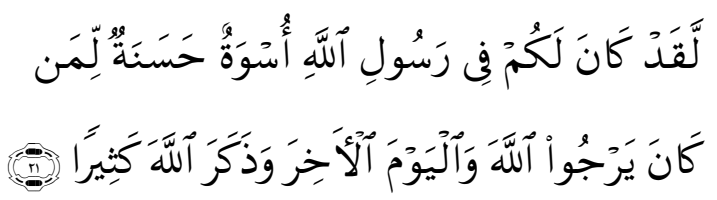

Artinya: "Sesungguhnya telah ada pada (diri) Rasulullah itu suri teladan yang baik bagimu (yaitu) bagi orang yang mengharap (rahmat) Allah dan (kedatangan) hari kiamat dan dia banyak menyebut Allah". (QS. Al-Ahzab, 33: 21).

Di samping jujur dan benar, sikap amanah sangat diperlukan dalam aktivitas ekonomi. Amanah berarti mengembalikan hak apa saja kepada pemiliknya, tidak mengambil sesuatu melebihi haknya dan tidak mengurangi hak orang lain, baik berupa harga atau upah (Al-Qardlawi, 175). Allah SWT berfirman:

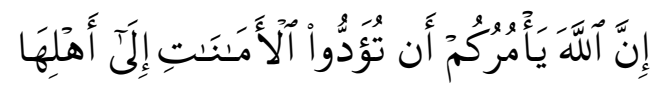

Artinya: "Sesungguhnya Allah menyuruh kamu menyampaikan amanat kepada yang berhak menerimanya”.(QS. Nisa, 4 58).

Bisnis dengan amanat dikenal dalam Islam seperti menjual dengan sistem murabahah dimana penjual menjelaskan ciri-ciri, kualitas, dan harga 
barang dagangan kepada pembeli tanpa melebihkannya. Amanat bertambah penting pada saat seseorang membentuk serikat dagang (musyarakah), melakukan bagi hasil (mudharabah), atau menitipkan barang untuk menjalankan proyek yang telah disepakati bersama (wa'diah). Dalam hal ini, pihak yang lain percaya dan memegang janji demi kemaslahatan bersama. Jika salah satu pihak menjalankannya hanya demi kemaslahatan dirinya sendiri, maka ia telah berkhianat.

Kompetensi kepemimpinan etika berkaitan dengan tingginya tingkat ketulusan hati dan penerapan aturan secara manusiawi. Hal ini dapat dilakukan dengan menghadapi faktorfaktor yang akan mempengaruhi kesadaran etika, cara berfikir, dan bertingkah laku serta lingkungan eksternal ( Idri dan Tutik, 2008:64). Kepemimpinan etika menuntut kesadaran bahwa proses penerapan nilai-nilai etika pada kehidupan ekonomi dewasa ini adalah proses yang sangat rumit karena semakin lama semakin besar data base, sementara knowledge base tidak berkembang secepatnya.

Kepemimpinan etika menghendaki adanya terobosan agar persoalanpersoalan yang bersangkut paut dengan ekonomi dapat dicari jalan keluarnya baik dalam perspektif etika secara benar menurut ketentuan etika itu.

Dalam penerapan keempat kompetensi di atas, menurut Kenneth E. Goodpaster, perlu diantisipasi faktor penghambat yang berupa karirisme (careerism), yaitu suatu pandangan hidup di mana identitas diri, ketulusan hati dan penentuan diri dari individu dihilangkan karena adanya perspektif bahwa diri adalah suatu objek yang gunanya tergantung pada nilai pasar. Careerism dapat menyebabkan kehancuran watak karena tidak memperbolehkan keseimbangan antara sifat kepala (traits of the head), misalnya inisiatif, kerja sama, fleksibilitas, ketenangan di situasi penuh tekanan (stres) dengan sifat hati (traits of the heart), misalnya kejujuran, keramahan, belaskasihan, kebaikan hati, dan idealisme (Idri dan Tutik, 2008:65). Dengan menghindari careerism, akan terjadi keseimbangan antara sifat kepala (traits of the head) dan sifat hati (traits of the heart) sehingga seseorang dapat melaksanakan keempat kompetensi di atas dengan baik.

\section{Sumber Daya Manusia Ekonomi Syariah}

Sumber Daya Manusia (SDM) yang berkualitas dan unggul merupakan salah satu diterminan yang sangat penting dalam pembangunan. Hal ini mengingat bahwa, manusia adalah penggerak dalam pembangunan yang mengantisipasi masalah, membuat perencanaan, mempertimbangkan sistem nilai agama dan masyarakat, menggali Sumber Daya Alam (SDA), mengakumulasi dana, membangun organisasi sosial, ekonomi dan politik, dan meletakkan semuanya dalam satu wadah "pembangunan" (Aziz dan Ulfah, 2010: 60).

SDM yang optimal memerlukan dua jenis kualitas, yaitu professional quality dan moral quality. Professional quality mengacu kepada kualitas kemampuan dan efisiensi kerja. Seorang operator mesin tidak akan dapat bekerja secara efisien seandainya tidak mengusai teknis mesin secara profesional. Dalam waktu yang sama operator tidak mungkin bekerja secara disiplin, tepat waktu, dan berdedikasi kepada pekerjaan tampa pamrih dan menghindari segala jenis korupsi (termasuk waktu dan komisi dalam 
pembelian suku cadang) seandainya tidak memiliki moral quality. Suatu hal yang sangat disayangkan, mainstream economics and management lebih menitikberatkan kepada professional quality dan kurang memperhatikan moral quality. Akibatnya, muncullah para teknokrat yang jenius dan profesional, tetapi berhati musang, dan tidak atau kurang mengindahkan tujuan dari pembangunan yang tercemin dalam amanah dan hajat hidup masyarakat banyak (Antonio 2001:353).

Secara jelas dan jitu, Islam menyambung missing link antara professional qulity dengan moral quality. Hal ini dilihat bahwasannya, Islam melihat bahwa manakala seorang bekerja untuk orang lain atau perusahaan ia telah memasuki sesuatu yang dipegang teguh dan tidak dapat diabaikan begitu saja. Allah SWT berfirman:

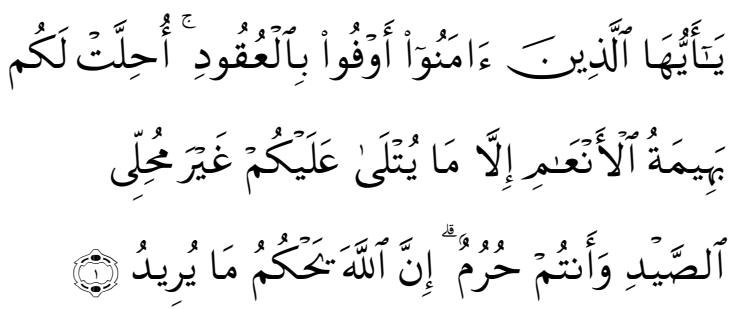

Artinya: "Hai orang-orang yang beriman, penuhilah aqad-aqad itu". (QS. Al-Maaidah, 5: 1).

Allah SWT mencela mereka yang manakala menerima, ingin mendapat takaran penuh tetapi manakala memberi, ingin menguranginya. Bila kita aplikasikan ke dalam SDM tepat bagi mereka yang tidak efisien dan bermalasmalasan tetapi mereka meminta gaji dengan penuh. Allah SWT berfirman:

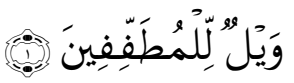

Artinya: "Kecelakaan besarlah bagi orang-orang yang curang, yang dimaksud dengan orang-orang yang curang di sini ialah orang-orang yang curang dalam menakar dan menimbang”. (QS. Al-Muthaffifiin, 83: 1). Adapun moral quality, menunjukkan bahwa dimensi moral yang dikehendaki untuk dikuasai SDM telah jelas digariskan. Moral quality adalah mengacu pada kemampuan SDM dalam meletakkan dirinya dalam menjalankan tugas kesehariannya sesuai dengan aturan-aturan permainan yang telah digariskan oleh Allah SWT (Muhammad, 2008:10).

Menurut Bambang Tri Cahyono masalah SDM dianggap penting disebabkan, antara lain: (1) Sebagai salah satu faktor produksi di samping modal, SDA dan teknologi; (2) Efektivitas SDM menentukan efektivitas faktor produksi lainnya; (3) Berciri sangat heterogen baik karena pembawaan kepribadian, maupun latar belakang pendidikan dan kultur; dan (4) Kapasitasnya tidak mudah diukur dan bersifat labil terhadap lingkungan (Aziz dan Ulfah, 2010: 61).

Dari empat sebab pentingnya SDM dalam aktvitas kehidupan, terutama dalam kegiatan ekonomi adalah professional quality dan moral quality. Namun dua aspek tersebut tidak akan berkesinambungan dan berimbang bila aspek iman dan ilmu nihil, nol. Sebab, Allah SWT menerangkan bahwa tingkat kemartabatan tidak akan diperoleh apabila ia tidak beriman dan berilmu. Ini artinya kualitas atau potensi pribadi tidak didukung dengan kualitas iman tidak akan signifikan.

Dalam rangka membangun kualitas SDM unggul diperlukan upayaupaya sadar untuk mentransformasikannya menuju kondisi yang lebih baik dan berdaya guna melalui pengembangan SDM yang Islami, dengan meningkatkan enam macam kekuatan, sebagai berikut: (1) Kekuatan iman (quwwatul iman); (2) Kekuatan 
ilmu (quwwatul ilmi); (3) Kekuatan moral (quwwatul akhlak); (4) Kekuatan semangat juang (quwwatul jihad); (5) Kekuatan ekonomi (quwwatul iqtishad); dan (5) Kekuatan kesetiakawanan (quwwatul tamasuk al-Ijtmia'iy).

B.J. Habibie, sebagaimana telah disinggung di atas, menyebutkan pula bahwa SDM yang unggul sangat diperlukan dalam rangka meningkatkan minimalitas pelayanan, dan itu menjadi acuan (reference) pula dalam keberhasilan kualitas kerja. Kualitas minimum dari SDM yang diperlukan perlu didukung oleh lima kriteria, sebagai berikut: (1) Kualitas iman (quality believe); (2) Kualitas pikir (quality idea); (3) Kualitas kerja (quality work); (4) Kualitas kreasi (quality creation); dan (5) Kualitas hidup (quality live).

Lima kriteria harus dapat dicapai oleh masyarakat yang sudah menikmati hidup di atas garis kemiskinan, dan ini menurut Habibie, disebut sebagai kualitas minimum SDM. Artinya, garis minimum adalah dimensi kesatu, kualitas minimum adalah dimensi kedua, dan pelayanan minimum adalah dimensi ketiga.

Dalam kaitannya dengan kegiatan ekonomi, kekuatan SDM dan lima kualitas di atas, nampaknya kekuatan dan kualitas iman dan ilmu, serta amal merupakan faktor penting dan dominan. Karena hal ini dianggap katalisator dari professional quality dan moral quality yang berujung pada fungsi manusia sebagai khalifah fi al-ardhi dan khalifah fi al-ardhi ini terwujud bila sifat-sifat ketuhanan telah mewarnai dirinya, "Jadilah kalian Rabbaniyyin" kata Allah. Artinya, sifat-sifat yang bersumber pada Al-Asma Al-Husna mampu besinergi dalam diri pribadi khalifah fii ardh, maka berdampak pada rahmatan lil 'alamin.

\section{Dunia Kerja Lulusan Sarjana Ekonomi Syariah}

Menurut Muhammad Syafi'i Antonio (2001:255), dunia kerja adalah tempat dimana seseorang menuangkan ilmu yang diperolehnya selama di bangku perkuliahan. Dunia kerja merupakan tujuan akhir yang ingin diraih setiap lulusan. Oleh sebab itu, Fakultas Agama Islam Universitas Islam Riau khususnya Program Studi Ekonomi Syariah mempersiapkan Kompetensi Lulusan Sarjana Ekonomi Syariah sehinggga berdaya guna dengan dunia kerjanya nanti, baik di bidang industri perbankan syariah maupun lembaga keuangan syariah lainnya.

Para Lulusan Sarjana Ekonomi Syariah diharapkan tidak saja akan memiliki kemampuan ilmiah yang cukup tinggi tentang ilmu ekonomi syariah, tetapi juga diharapkan mampu mengembangkan dan mengelola dunia kerja seperti lembaga-lembaga bisnis syariah, lembaga swadaya masyarakat, dan lembaga pendidikan atau penelitian yang berkaitan dengan ekonomi syariah secara keseluruhan. Lembaga-lembaga yang dimaksud antara lain (Rodoni dan Hamid, 2008:5-6).

\section{Upaya FAI UIR Prodi Ekonomi Syariah dalam Mempersiapkan Kompetensi Lulusan Sarjana Ekonomi Syariah Kurikulum dan Dosen}

Dalam Buku Pedoman FAI UIR tahun 2013, suatu lembaga pendidikan bisa dikatakan bermutu apabila mempunyai standar kualitas, seperti input, proses dan output. Input yaitu penyusunan kurikulum, ketersediaan tenaga pendidik, yaitu dosen dan tenaga pendidikan yang terdiri dari pimpinan sampai dengan bawahan, adanya mahasiswa, sarana dan prasarana, manajemen pendidikan, serta 
mempunyai laporan keuangan. Proses, yaitu proses perkuliahan/akademik, dan terakhir adalah output, baik itu mahasiswa maupun alumni harus memiliki prestasi akademik yang baik dan akan lebih baik lagi jika mereka mempunyai prestasi luar akademik.

Sebagaimana dengan hal-hal yang telah dijelaskan di atas, maka untuk mencetak Lulusan Sarjana Ekonomi Syariah yang profesional dan mempunyai moral serta etika, yang berkompeten dalam bidang keahliannya, yang mampu mengelola industri perbankan syariah dan lembaga-lembaga keuangan syariah lainnya, sangat ditentukan oleh kurikulum dari suatu institusi pendidikan. Kurikulum adalah perangkat mata kuliah untuk suatu bidang keahlian khusus (Team Pustaka Phoenix, 2008:514). Oleh sebab itu, dalam merespon kebutuhan di atas, FAI UIR Prodi Ekonomi Syariah menyusun kurikulum dan menyediakan tenaga pengajar, yaitu dosen. Penyusunan kurikulum, ketersediaan dosen yang relevan dengan jurusan, menyusun rencana strategi dan visi, misi serta tujuan ekonomi syariah, ini merupakan persyaratan utama dalam menciptakan Lulusan Sarjana Ekonomi Syariah dengan kompetensi yang dicari oleh lembaga-lembaga yang disebutkan di atas.

Dalam menyusun kurikulum, hal
yang perlu diperhatikan adalah
melibatkan pihak-pihak yang memang
bergerak di bidang ekonomi syariah,
seperti Masyarakat Ekonomi Syariah
(MES), begitu pula dalam merevisi
kurikulum, perlu mengadakan
workshop yang juga melibatkan pihak-
pihak yang bergerak di bidang ekonomi
syariah, agar kurikulum yang disusun
nantinya bermafaat dan berdaya guna
dengan dunia kerja para lulusan.

\section{Sarana dan Prasarana}

Ketersediaan ruang dan segala fasilitas yang dimiliki oleh FAI UIR sangat berkaitan dengan proses perkuliahan mahasiswa ekonomi syariah. Tanpa dukungan sarana dan prasarana proses belajar mengajar perkuliahan tidak akan terlaksana. Sarana adalah segala sesuatu yang dapat dipakai baik berupa alat atau media (Team Pustaka Phoenix, 2008:762). Sedangkan prasarana adalah segala sesuatu yang menunjang proses perkuliahan tersebut (Salim dan Yenny, 2002: 1188).

Oleh sebab itu, agar aktivitas perkuliahan dapat berjalan dengan baik dan lancar, dibutuhkan sarana dan prasarana yang representatif. Sarana yang paling terpenting adalah ruang perkuliahan. Tanpa ruang perkuliahan proses belajar mengajar tidak akan berlangsung. Dalam hal ini, FAI UIR Prodi Ekonomi Syariah menyediakan 7 ruang perkuliahan lama dan ditambah 8 ruang perkuliahan baru yang masingmasing ruangan tersebut dilengkapi dengan infokus. Proses perkuliahan mahasiswa ekonomi syariah tentunya perlu didukung dengan labor komputer ekonomi syariah. Selain itu, FAI UIR Prodi Ekonomi Syariah menyediakan ruangan dosen, ruangan untuk Ketua Jurusan, Staf Tata Usaha, Dekan, Wakil Dekan I, Wakil Dekan II, Wakil Dekan III, ruang rapat, aula, ruang sidang untuk skripsi, perpustakaan dengan jumlah buku sebanyak 1500 buku, Badan Ekskutif Mahasiswa (BEM), Dewan Mahasiswa (DEMA), dan kantin.

Selain itu, UIR juga menyediakan prasarana yang berkaitan dengan kegiatan ekonomi, yaitu Bank Unistrama, Bank Kas Syariah Mandiri, fasilitas Aoutomatic Teller Mesin (ATM Bank Syariah Mandiri, Bukopin, dan Bank Muamalat), serta fasilitas pendukung lainnya, seperti 
perpustakaan UIR, laboratorium komputer (BAIT), fasilitas WIFI, masjid dan lapangan bola. Tanpa sarana dan prasarana yang disebutkan di atas mungkin Lulusan Sarjana Ekonomi Syariah yang unggul tidak dapat tercipta karena sarana dan prasarana merupakan salah satu faktor penting dalam menciptakan Lulusan Sarjana Ekonomi Syariah.

\section{METODE PENELITIAN}

Dalam penelitian ini yang dijadikan populasi adalah seluruh Lulusan Sarjana Ekonomi Syariah Fakultas Agama Islam Universitas Islam Riau sebanyak 61 lulusan. Adapun jumlah sampel ditentukan berdasarkan rumus Slovin (Muhamad, 2008:180): Dalam penelitian ini jumlah populasi $(\mathrm{N})$ $=61$ orang, dengan nilai kritis $(e)$ sebesar $10 \%$ maka ukuran sampel:

$$
n=\frac{61}{1+(61)(10 \%)^{2}}=37,9
$$

Jadi, dalam penelitian ini ukuran sampelnya dibulatkan sebanyak 38 lulusan, dan teknik pengambilan sampel dalam penelitian ini adalah menggunakan purposive sampling, yaitu teknik nonprobability sampling yang memilih orang-orang yang terseleksi oleh peneliti berdasarkan ciri-ciri khusus yang dimiliki sampel tersebut yang dipandang mempunyai sangkut paut erat dengan ciri-ciri atau sifat-sifat populasi yang sudah diketahui sebelumnya.

Sumber data yang digunakan dalam penelitian ini adalah: Data primer, yaitu data yang diperoleh melalui penelitian langsung ke lokasi atau responden dan data sekunder, yaitu data yang diperoleh dari bacaan literatur yang berkaitan dengan masalah yang diteliti.Teknik Pengumpulan Data yang digunakan adalah: Pertama; Angket (questionier), yaitu menyebarkan daftar pernyataan guna mempermudah di dalam pelaksanaan pengumpulan data. Pernyataan yang dirancang untuk mengukur variabel bebas, yaitu kompetensi Lulusan Sarjana Ekonomi Syariah dan variabel terikat, yaitu dunia kerja. Pengukuran variabel dilakukan dengan menggunakan skala tiga alternatif pilihan Setuju= Skor 3 ; Ragu-ragu = Skor 2 Tidak Setuju = Skor 1. (Hadari Nawawi dan Martini Hadari, 2006:123).

Kedua; Wawancara (interview), yaitu penulis menanyakan langsung kepada Ketua Jurusan Ekonomi Syariah guna memperoleh informasi yang berkaitan dengan Studi Ekonomi Syariah. Ketiga; Dokumentasi (Documentation), yaitu penulis akan menyimpulkan dari bahanbahan dokumen Fakultas Agama Islam Universitas Islam Riau, khususnya Program Studi Ekonomi Syariah yang berhubungan dengan masalah yang akan diteliti.

Teknik pengolahan data dilakukan, sebagai berikut (Dairi, 2010:77): Penyuntingan (editing), yaitu data yang telah dikumpulkan selama penelitian akan diperiksa dengan cara mengoreksi data tersebut untuk memperoleh data yang tepat dan benar; Pengkodean (coding), yaitu dengan cara memberikan tanda (kode) terhadap data yang dikategorikan sama; dan Pentabulasian (tabulating), yaitu menyusun hasil dari anket tentang penelitian dimaksud, kemudian dituangkan dalam bentuk tabel.

Teknik Analisis Data yang digunakan dalam penelitian ini adalah analisis kualitatif dan kuantitatif. Analisis kualitatif yaitu analisis yang digunakan untuk penganalisisan secara argumentatif berdasarkan data-data yang bersifat karakteristik (jenis kelamin dan pekerjaan) atas jawaban kuesioner yang diperoleh dari Lulusan 
Sarjana Ekonomi Syariah Fakultas Agama Islam Universitas Islam Riau.

Sedangkan analisis kuantitatif adalah analisis yang digunakan untuk menganalisis data secara statistik, dengan menggunakan Analisis Korelasi Spearman Rank, yaitu analisis yang digunakan untuk mengukur keeratan hubungan antara dua variabel. Korelasi ini tidak mensyaratkan distribusi normal dan bisa memakai data tipe ordinal. Sedangkan, pengolahan datanya menggunakan program computer SPSS for windows versi 17.0 (Priyatno, 2009:114).

Kuesioner yang digunakan dalam penelitian ini menggunakan Skala Guttman, maka terlebih dahulu data kuesioner yang sudah berhasil dikumpulkan akan dilakukan pengujian terlebih dahulu. Pengujian yang dilakukan adalah Uji Validitas dan Reliabilitas. Setelah data dinyatakan valid dan reliabel, kemudian baru dilakukan Analisis Korelasi Spearman Rank dan Uji Signifikansi (Uji t).
Uji Validitas adalah ketepatan atau kecermatan suatu instrumen dalam mengukur apa yang ingin diukur. Uji validitas sering digunakan untuk mengukur ketepatan suatu item dalam kuesioner atau skala, apakah item-item pada kuesioner tersebut sudah tepat dalam mengukur apa yang ingin diukur. Uji validitas yang digunakan adalah uji validitas item. Validitas ditunjukkan dengan adanya korelasi atau dukungan terhadap item total (skor total), perhitungan dilakukan dengan cara mengkorelasikan antara skor item dengan skor total item. Dari perhitungan korelasi akan didapat suatu koefisien korelasi yang digunakan untuk menentukan apakah suatu item layak digunakan atau tidak (Priyatno, 2010:90).

\section{HASIL PENELITIAN DAN PEMBAHASAN}

Berdasarkan hasil penelitian menunjukkan bahwa berdasarkan deskripsi data sebagai berikut:

Tabel 2

Jenis Kelamin Lulusan Sarjana Ekonomi Syariah

\begin{tabular}{ccc}
\hline Jenis Kelamin & Jumlah (Orang) & Persentase (\%) \\
\hline Laki-laki & 24 & 63 \\
\hline Perempuan & 14 & 37 \\
\hline Total & $\mathbf{3 8}$ & $\mathbf{1 0 0}$ \\
\hline
\end{tabular}

Dari tabel di atas, terlihat bahwa untuk jenis kelamin Lulusan Sarjana Ekonomi Syariah diketahui sebanyak 24 orang atau $63 \%$ berjenis kelamin lakilaki, sedangkan lebihnya sebanyak 14 orang atau $37 \%$ berjenis kelamin perempuan.

\section{Pekerjaan}

Pekerjaan merupakan faktor yang sangat berpengaruh dalam melihat sejauhmana kompetensi Lulusan Sarjana Ekonomi Syariah yang dimiliki dalam dunia kerja yang digelutinya, sebagai berikut: 
Tabel 3

Pekerjaan Lulusan Sarjana Ekonomi Syariah

\begin{tabular}{|c|c|c|}
\hline Pekerjaan & $\begin{array}{l}\text { Jumlah } \\
\text { (Orang) }\end{array}$ & $\begin{array}{c}\text { Persentase } \\
(\%)\end{array}$ \\
\hline Lembaga Keuangan Syariah & 9 & 24 \\
\hline Lembaga Keuangan Non Syariah & 6 & 16 \\
\hline Instansi Pemerintahan, PT, CV, Perusahaan Swasta & 7 & 18 \\
\hline Lembaga Pendidikan & 10 & 26 \\
\hline Lembaga Sosial & 2 & 5 \\
\hline Wirausahaan & 4 & 11 \\
\hline Total & 38 & 100 \\
\hline
\end{tabular}

Dari tabel di atas, terlihat bahwa untuk pekerjaan Lulusan Sarjana Ekonomi Syariah diketahui sebanyak 9 orang atau $24 \%$ yang bekerja di lembaga keuangan syariah, 6 orang atau $16 \%$ yang bekerja di lembaga keuangan non syariah, 7 orang atau $18 \%$ yang bekerja di instansi pemerintahan, PT, $\mathrm{CV}$, dan Perusahaan Swasta, 10 orang atau $26 \%$ yang bekerja di lembaga pendidikan, 2 orang atau 5\% yang bekerja di lembaga sosial, dan selebihnya 4 orang atau $11 \%$ yang bekerja sebagai wirausahaan.

Berdasarkan deskripsi di atas, dapat disimpulkan bahwa sebesar 40\% dari 38 Lulusan Sarjana Ekonomi Syariah yang diteliti, sudah bekerja sesuai dengan jurusan, yaitu bekerja di lembaga keuangan syariah, lembaga sosial, dan menjadi wirausahaan.

\section{Analisis Kompetensi Lulusan Sarjana Ekonomi Syariah dalam Dunia Kerja}

Kompetensi merupakan suatu konsep pendidikan yang menekankan pada pengembangan kemampuan dalam melaksanakan tugas-tugas dengan standar performansi tertentu sehingga hasilnya dapat dirasakan oleh peserta didik berupa penguasaan terhadap seperangkat kompetensi tertentu. Dalam bahasa lain kompetensi dimaknai sebagai seperangkat tindakan cerdas penuh tanggung jawab yang dimiliki seseorang sebagai syarat untuk dianggap mampu oleh masyarakat dalam melaksanakan tugas-tugas di bidang pekerjaan tertentu.

\section{Pembahasan}

Berdasarkan hasil penelitian, diketahui bahwa walaupun Lulusan Sarjana Ekonomi Syariah ada yang bekerja sesuai dengan jurusan sebesar 50\%, dan sebesar 21\% Lulusan Sarjana Ekonomi Syariah ada yang tidak bekerja sesuai dengan jurusan, sedangkan lebihnya sebesar 29\%, keahlian/jurusan lulusan hanya berkaitan dengan bidang pekerjaannya saja (tidak untuk dunia kerja lulusan).

Namun, wujud kompetensi Lulusan Sarjana Ekonomi Syariah dalam dunia kerja sangat tampak, dengan bekal kompetensi yang diperolehnya selama bangku perkuliahan dapat diterapkan dan mendukung pekerjaan mereka dalam dunia kerja, seperti skill atau mampu dalam menyelesaikan tugas (tanggung jawab), mampu dalam mengaplikasikan komputer (teknologi informasi), memiliki sikap profesional dalam bekerja, mampu dalam beradaptasi baik dengan lingkungan kerja maupun dengan tugas (tanggung jawab), mengusai dasar-dasar akuntansi, perbankan syariah, dan manajemen syariah, mampu menjalani kegiatan ekonomi sesuai dengan ajaran 
Islam, mampu mengembangkan ide-ide kreatif dan inovatif, mampu berkomunikasi secara efektif dan efisien dengan siapapun, mampu membuat keputusan dan belajar dari setiap kejadian, dan memiliki rasa kepercayaan diri serta etos kerja.

Analisis akhir yang dapat disimpulkan, yaitu pertama: hasil kompetensi lulusan sarjana ekonomi syariah dalam dunia kerja menunjukkan hasil yang positif dan signifikan, dimana melalui hasil uji signifikansi atau uji $\mathrm{t}$ diketahui $t_{\text {hitung }}$ sebesar 6,448 ternyata lebih besar dibandingkan dengan $t_{\text {tabel }}$ sebesar 2,028. Adapun nilai hubungannya atau Koefisien Korelasi Spearman Rank sebesar 0,732 dengan tingkat hubungan "kuat". Sedangkan hasil kompetensi Lulusan Sarjana Ekonomi Syariah dalam dunia kerja sebesar $53,60 \%$ dan sebesar $46,40 \%$ dipengaruhi oleh faktor lainnya. Kedua: Upaya yang dilakukan oleh Fakultas Agama Islam Universitas Islam Riau Program Studi Ekonomi Syariah dalam mempersiapkan kompetensi Lulusan Sarjana Ekonomi Syariah antara lain menyusun kurikulum yang sesuai dengan permintaan dunia kerja khususnya lembaga keuangan syariah dan lembaga-lembaga keuangan lainnya, menyediakan dosen yang relevan dengan jurusan, menyusun rencana strategi, serta menyediakan sarana dan prasarana ternyata terbukti bermanfaat dan berdaya guna bagi kompetensi Lulusan Sarjana Ekonomi Syariah itu sendiri dalam dunia kerja.

\section{PENUTUP}

Berdasarkan hasil penelitian dan pembahasan yang telah dipaparkan di atas, maka dapatlah ditarik kesimpulan yaitu: Pertama, Hasil penelitian menunjukkan bahwa kompetensi Lulusan Sarjana Ekonomi Syariah dalam dunia kerja menunjukkan hasil yang baik, hal ini terbukti dari hasil penelitian, dimana melalui hasil uji dari beberapa variabel penelitian tentang penguasaan materi ilmu ekonomi syariah dalam dunia kerja yang mereka geluti menunjukkan hasil yang positif, dengan range penguasaan $80 \%$ s.d $97 \%$ dari $38 \%$ lulusan yang diteliti hampir semua lulusan mampu menganalisis dari sisi syariah terhadap teori/materi ekonomi syariah dan berdasarkan deskripsi di atas, dapat disimpulkan bahwa sebesar 58\% dari 38 lulusan yang diteliti, sebagian dari lulusan menyatakan kompetensi ekonomi syariah yang mereka miliki sangat bermanfaat dengan dunia kerja.

Kedua, upaya yang dilakukan oleh Fakultas Agama Islam Universitas Islam Riau dalam mempersiapkan kompetensi Lulusan Sarjana Ekonomi Syariah antara lain menyusun kurikulum sesuai dengan tuntutan dunia kerja, menyediakan dosen yang relevan dengan jurusan, menyusun rencana strategi, serta upaya pendukung lainnya seperti menyediakan sarana dan prasarana ternyata terbukti bermanfaat dan berdaya guna bagi kompetensi Lulusan Sarjana Ekonomi Syariah itu sendiri dalam dunia kerja.

Setelah menelaah dan membahas permasalahan dalam penelitian ini, penulis menyarankan: Pertama; Fakultas Agama Islam Program Studi Ekonomi Syariah perlu meningkatkan lagi ketersediaan dosen yang memadai (memiliki kualifikasi di bidangnya). Kedua; Program Studi Ekonomi Syariah meningkatkan penyusunan kurikulum yang sesuai dengan tuntutan dunia kerja sehingga menghasilkan Lulusan Sarjana Ekonomi Syariah yang memiliki kompetensi yang berkualitas, Ketiga; Program Studi Ekonomi Syariah untuk meningkatkan lagi kemampuan/ keahlian lulusan (di luar mata kuliah 
wajib yang dikuasai lulusan) sehingga dapat diterapkan dalam dunia kerja, seperti aplikasi komputer baik akuntansi maupun perbankan syariah. Keempat; Fakultas memperbanyak lagi buku-buku referensi ekonomi syariah. Kelima; Program Studi Ekonomi Syariah meningkatkan akses teknologi tentang kumpulan tulisan ekonomi syariah. Keenam; Program Studi meningkatkan temu alumni secara periodik yaitu melakukan pertemuan berkala dengan sivitas akademika di Fakultas Agama Islam Universitas Islam; Ketujuh; Mahasiswa diharapkan mempersiapkan kompetensinya sebelum berkecimpung di dunia kerja dan Prodi melakukan rekapitulasi data alumni secara kontinyu.

\section{DAFTAR RUJUKAN}

Ali, Zainudin. 2010. Hukum Perbankan Syariah Cetakan kedua (Edisi Pertama). Jakarta: Sinar Grafika.

Aziz, Abdul dan Ulfah, Mariya. 2010. Kapita Selekta Ekonomi Islam Kontemporer. Bandung: Alfabeta.

Admin, http://id.wikipedia.org/wiki/ Hubungan, 2010.

Admin, http://isjd.pdii.lipi.go.id/admin/ jurnal, 2012.

Admin, http://www.stis-sbi.com/p/ program-studi-ekonomi-syariah. html, 2012.

Agni Alam Awirya dan Indah Piliyanti, Menakar Kesiapan Mahasiswa Ekonomi Syariah Menghadapi Pasar Tenaga Kerja, Journal of Islamic and Economic, Volume 2, No. 1, Juni 2008.

Antonio, Muhammad Syafi'i. 2001. Bank Syariah Dari Teori Ke Praktik Cetakan Pertama. Jakarta: Gema Insani.

Dairi, Rizal. 2010. Metodologi Penelitian Berbasis Kompetensi. Pekanbaru: UIR Press.
Departemen Agama RI. 2004. Al-Qur'an Dan Terjemahannya. Semarang: PT. Karya Toha.

Fajar Luhur Martha, "Kesiapan Mahasiswa Menghadapi Pasar Tenaga Kerja Di Bidang Ekonomi Syariah Sebagai Respon Atas Perkembangan Praktik Ekonomi Syariah Di Indonesia (Studi Kasus Sekolah Tinggi Ekonomi Syariah)", Jakarta, 2007.

Fauroni, Lukman. 2006. Arah Dan Strategi Ekonomi Islam Cetakan Pertama. Yogyakarta: Magistra Insania Press.

Idri dan Tutik, Titik Triwulan. 2008. Prinsip-Prinsip Ekonomi Islam. Jakarta: Lintas Pustaka.

Hasan, M. Iqbal. 2010. Pokok-Pokok Materi Statistik 2 (Statistik Inferensif) Edisi Kedua Cetakan Keenam. Jakarta: Bumi Aksara.

Kamus Besar Bahasa Indonesia. 2008. Jakarta: PT. Gramedia Pustaka Utama.

Menur Widilaksmi, $\quad \underline{\text { http:// }}$ id.jobsdb.com/kompetensi dunia kerja, 2012.

Muhamad. 2008. Metodologi Penelitian Ekonomi Islam Edisi Pertama. Jakarta: Rajawali Pers.

Mujahidin, Akhmad. 2010. Ekonomi Islam 2. Pekanbaru: Al-Mujtahadah Press.

Mulyasa. 2010. Kurikulum Berbasis Kompetensi (Konsep, Karakteristik, Dan Implementasi. Bandung: PT. Remaja Rosdakarya.

Naqvi, Syed Nawab Haider. 2003. Menggagas Ilmu Ekonomi Islam Cetakan Pertama. Yogyakarta: Pustaka Pelajar.

Nawawi, Ismail. 2009. Ekonomi Islam (Perspektif Teori, Sistem Dan Aspek Hukum). Surabaya: CV. Putra Media Nusantara.

Nawawi, Hadari dan Hadari, Martini. 2006. Instrumen Penelitian Bidang 
Sosial. Yogyakarta: Gadjah Mada University Press.

Nugroho, Yohanes Anton. 2011. It's Easy Olah Data dengan SPSS Cetakan Pertama. Yogyakarta: Skripta Media Creative.

Nursyam Sunan Ampel, http://nursyam.sunanampel.ac.id/, 2012.

Purwanto, Djoko. 2008. Panduan Lengkap Memasuki Dunia Kerja. Surakarta: Esensi Erlangga Group.

Priyatno, Duwi. 2009. 5 Jam Belajar Olah Data dengan SPSS 17. Yogyakarta: Andi.

Priyatno, Duwi. 2010. Paham Analisa Statistik Data Dengan SPSS Cetakan Pertama. Yogyakarta: Media Kom.

Riduwan. 2008. Dasar-Dasar Statistika Cetakan Keenam. Bandung: Alpabeta.

Riduwan dan Sunarto. 2011. Pengantar Statistika Untuk Penelitian Pendidikan, Sosial, Ekonomi, Komunikasi, Dan Bisnis Cetakan
Keempat. Alpabeta: Bandung, 2011.

Redaksi, http://hminews.com/news/ gelar-akademik-yang-baru/, 2010.

Rodoni, Ahmad dan Hamid, Abdul. 2008. Lembaga Keuangan Syariah. Jakarta: Zikrul Hakim.

Salim, Peter dan Yenny. 2002. Kamus Bahasa Indonesia Kontemporer Edisi Ketiga. Jakarta: Modern English Pers: Jakarta.

Sugiyono. 2012. Statistika Untuk Penelitian Cetakan Ke-20. Bandung: Alpabeta.

Team Pustaka Phoenix. 2008. Kamus Besar Bahasa Indonesia Cetakan Ketiga (Revisi). Jakarta: PT. Media Pustaka Phoenix.

Usman, A. Rani. 2001. Kampus Sebagai Institusi Pencerahan. NAD: Fakultas Dakwah IAIN Ar-Raniry.

Yangjepe, yandjepe's Blog, 2012.

Yulaelawati, Ella. 2004. Kurikulum Dan Pembelajaran (Filosofi, Teori, Dan Aplikasi) Cetakan Pertama. Jakarta: Pakar Raya. 